DOI: 10.14526/2070-4798-2019-14-4-119-128

\title{
The problem of future specialists' professional training in the field of physical culture to work in an inclusive education
}

\author{
Valeriy G. Shubovich*, Olga V. Vakhteeva, Alena N. Alenova \\ Ulyanov State Pedagogical University, Ulyanovsk \\ Ulyanovsk, Russia \\ ORCID: oooo-ooo3-3512-7653, shubvg@mail.ru* \\ ORCID: Oooo-0oo2-5999-6338, olgavachteevao9@gmail.com \\ ORCID: Oooo-0oo2-0824-2966, waterfall-_-@mail.ru
}

\begin{abstract}
The article deals with the problem of students' vocational training in higher education for activities in conditions of inclusive education. Inclusive education is a system that ensures equal access to education and education in the educational space for all students without exception, taking into account their diverse special educational needs. Materials. The article reveals the concept of "vocational training of future teachers in the university to work in conditions of inclusive education" as a system of students training in the university using specific approaches, interactive forms and techniques in the educational process of the university in order to prepare students for the mastering and application of psycho-pedagogical technology and techniques, including inclusive, not necessary for working with children with disabilities; To create a positive psychological climate between children with disabilities and the norm of development with the inclusion of all students in the educational process. Research methods. Author's questionnaire "Readiness of future teachers to work with children with disabilities" to determine the level of students - future teachers readiness to work with children with disabilities. Results. Levels (optimal, sufficient and low) and components of future teachers readiness formation in the university to work with children with disabilities have been determined. The experience of future teachers readiness formation selected components practical implementation in the university to work with children with disabilities with the help of a special program using active methods of education is described: Mini-lecture, working with text, game methods, solving situational problems, working in small groups, discussions, brain storming, business games, project development, participation in web conferences, discussions, use of internships and practices on the bases of educational organizations, where work with children with disabilities is presented at a high professional level, etc. The study shows the dynamics of future teachers readiness formation in the university to work with children with disabilities. Conclusion. The study of the vocational training problem in the university for future teachers work in conditions of inclusive education proved that the active life position of students, specially created educational conditions for obtaining additional theoretical knowledge using active and interactive forms of education, as well as the acquisition of deep practical skills, contribute to increasing the level of future teachers readiness in the university for activities with children with disabilities.

Keywords: vocational training at the university, specialists in the field of physical culture, inclusive education, inclusive educational space.
\end{abstract}

For citation: Valeriy G. Shubovich*, Olga V. Vakhteeva, Alena N. Alenova. The problem of future specialists' professional training in the field of physical culture to work in an inclusive education. Russian journal of Physical Education and Sport. 2019; 14(4): 100-106. DOI: 10.14526/2070-4798-2019-14-4-119128 .

\section{INTRODUCTION}

Currently, the number of children with disabilities is growing. This category includes children with severe speech disorders, hearing and vision disorders, musculoskeletal system, emotional sphere, with complex developmental disabilities. The law "on education" of the Russian Federation officially adopted the definition of "inclusive education" as a system that provides all students, taking into account their various special educational needs, equal access to education and upbringing (art. 2, p. 27) [7].

The development of the inclusive education system in the Russian Federation is an important direction of modern domestic educational policy. According to Russian legislation, every child with limited health or disability has the right to receive education at the place of residence, therefore, such 
a "special" child can appear in any educational organization [8]. The specificity of inclusive education in modern conditions is that children with disabilities have the right to study together with their normally developing peers in the space of a single educational organization, but on different educational routes. All this means that a modern teacher should be ready to implement pedagogical activities in an inclusive educational space [9].

This fact is confirmed by a number of international and Federal normative documents, such as the Convention on the rights of the child, the Federal law " on education "(2012), the Federal Law "on social protection of disabled people in the Russian Federation" (2016), the Decree of the Russian Federation President, May 7, 2012 No. 597 "on measures to implement the state social policy", the State program of the Russian Federation "Accessible environment" for 2011-2020, the Interdepartmental comprehensive plan of measures to ensure the availability of vocational education for the disabled and persons with disabilities for 20162018, etc.

In item 1 of the presidential Decree, May 7, 2012 № 597 "On measures of state social policy realization" is defined as a priority task - by 2020, the need to increase the number of highly qualified specialists in educational institutions, so it was more than a third of the total organizations qualified employees [6].

The problem of training teachers-specialists in working with children with disabilities - is relevant and is represented in a number of dissertations, works of theorists and practitioners-A. A. Bodalev, L. S. Podymova, S. L. Rubinstein; aspects of inclusive education are considered in the works of S. V. Alyokhina, D. I. Gavrilova, T. I. Kozhekina, A. A. Levitskaya, N. M. Nazarova, V. V. Rubtsov, N. ya. Semago, A. Ya. Chigirina, V. S. Shilov, etc.

In modern conditions, the readiness of teachers to work in the system of inclusive education is one of the state policy success components in the field of inclusion, which is due to the following factors: the functional responsibilities of teachers are significantly expanded, increasing the requirements for the level of their professional competence. According To L. V. Goryunova, relying on the previous, traditional skills, the teacher is no longer able to perform new functional duties and labor actions; therefore, a modern teacher must have an inclusive competence as a component of professional competence that ensures the implementation of effective pedagogical activity in the conditions of an inclusive education system [1, p. 87].

Currently, the training of teachers for the system of inclusive education is one of the most relevant for modern pedagogical theory and practice. The professional standard " Teacher (pedagogical activity in the field of preschool, primary general, basic general, secondary general education) (educator, teacher)" imposes requirements on the modern teacher (educator) to perform a variety of labor functions, including the following skills: "To use and test special approaches to training in order to include all students in the educational process»; readiness "To master and apply psychological and pedagogical technologies (including inclusive), necessary for targeted work with different groups of students"; ability "To create a positive psychological climate in the group and conditions for friendly relations between children..."and" Use special corrective training techniques for children with disabilities" [2].

As practice shows, the set of a modern University graduate competencies, defined by the Federal state educational standards of higher education enlarged group of specialties and directions 44.00.00 - Education and pedagogical sciences, only partially meets the requirements of the modern system of inclusive education. A careful analysis of the texts in the areas of the baccalaureate (44.03.01 - Teacher education and 44.03.05 Pedagogical education (with two profiles)) and master (44.04.01 - Teacher education) (table 1) it can be noted that FSES of higher education bachelor training 44.03.01 - Teacher education establishes the formation of only one competence GPC-6; FSES of higher education-bachelor's degree in the direction of training 44.03.05 Pedagogical education (with two training profiles) establishes the formation of two competencies - GPC-3, GPC-6, which meet the needs of the University graduate to qualitatively and effectively perform labor functions related to work in an inclusive education $[3,4,10]$. 
Table 1-Comparative characteristics of the GEF and established competencies

\begin{tabular}{|c|c|c|}
\hline № & FSES & Established competence \\
\hline 1. & $\begin{array}{c}\text { Federal state educational standard } \\
\text { higher education-bachelor's } \\
\text { degree in the field of training } \\
\text { 44.03.01 Pedagogical education }\end{array}$ & $\begin{array}{c}\text { GPC-6-is able to use psychological and pedagogical } \\
\text { technologies in professional activities necessary for } \\
\text { individualization of training, development, education, } \\
\text { including students with special educational needs }\end{array}$ \\
\hline 2. & $\begin{array}{c}\text { Federal state educational standard } \\
\text { higher education-bachelor's } \\
\text { degree in the field of training } \\
\text { 44.03.05 Pedagogical education } \\
\text { (with two training profiles) }\end{array}$ & $\begin{array}{c}\text { GPC-3-is able to organize educational and educational } \\
\text { activities of students, including those with special } \\
\text { educational needs, in accordance with the requirements of } \\
\text { the FSES; } \\
\text { GPC -6-is able to use psychological and pedagogical } \\
\text { technologies in professional activities necessary for } \\
\text { individualization of training, development, education, } \\
\text { including students with special educational needs }\end{array}$ \\
\hline
\end{tabular}

At the same time, we note that in of the methodological foundations of teachers the enlarged group of areas and specialties 44.00.00 - Education and pedagogical sciences, professional training system to work with a number of training areas for bachelors and children with disabilities; between the need to develop the theoretical foundations of an masters are presented. Within them whole blocks of competencies are formulated that determine the readiness of graduates to perform quality labor functions both after graduation from the bachelor's degree and after receiving higher education - at the master's level. We are talking, for example, about training in the areas of 44.03.02 - Psychological and pedagogical education, 44.03 .03 - Special (defectological) education (bachelor's level); 44.04.02 Psychological and pedagogical education, 44.04.03 Special (defectological) education (master's level).

E. S. Romashevskaya argues that only a teacher-psychologist, a defectologist and a social teacher are actually ready to work in an inclusive education after graduation, while a subject teacher who encounters a special child in an ordinary class of a secondary school is practically not ready for the quality performance of his work functions [5, p. 63-68].

Thus, contradictions were revealed between the demand for professional training and insufficient attention to the development integrated system and insufficient attention to its theoretical foundations, revealing the potential of professional training in a pedagogical University.

\section{MATERIALS AND METHODS}

In order to identify effective conditions for the training of future teachers, a research was conducted. It includes three stages (ascertaining, forming, control), during which the levels of students-future teachers readiness to work with children with disabilities were prepared and diagnosed. The study was conducted on the basis of Ulyanov State Pedagogical University, Ulyanovsk in 2019. Two groups of the 3 rd year students attended the experiment. They represented pedagogy and psychology faculty, direction of training "Primary education/ computer science". The total number of respondents was 36 people. Determination of the students-future teachers readiness level to work with children with disabilities was carried out using the author's questionnaire "Readiness of future teachers to work with children with disabilities".

\section{RESULTS AND DISCUSSION}

At the ascertaining stage of the experiment, using the author's questionnaire, diagnostics was carried out to determine the level of students- 
future teachers readiness to work with children with disabilities. It was revealed that 3 students (8.3\%) of the respondents had previously worked with children with disabilities and described the following disorders: ASD (autism spectrum disorder of children), cerebral palsy( cerebral palsy), speech disorders, and 16 students (44.4\%) had no similar experience of interaction and work with children with disabilities.

17 students (47.2\%) were able to reflect the main essence of the "inclusive education" definition. In their responses, using various definitions and formulations, they interpreted the concept of inclusive education as ensuring equal access to education and upbringing for all students without exception. They took into account their individual capabilities and special educational needs; 2 students (11\%) could not explain in their response the meaning of the term "inclusive education".

Working with the questionnaire, 3 students $(8,3 \%)$ were not able to characterize a child with disabilities using adjectives; 16 students $(44,4 \%)$ indicated an average of 5 adjectives characterizing children of the discussed category. So, the most common characteristics of children with disabilities, according to future teachers, were: closed - in 14\% of respondents, kind-11\%, unique- $7 \%$, diligent- $5 \%$, unsociable- $3 \%$.

In response to the questionnaire question concerning the definition of positive and negative aspects, according to respondents, available in the organization of inclusive education in a modern educational organization, such positive factors as the involvement of children with disabilities in active life, socialization for special children, familiarization of children with the norm to help children with disabilities, education of children, regardless of health status-22 people (61\%).

The negative aspects that occur in the organization of inclusive education, future teachers attributed: a small number of specialists and equipment in the educational environment, the difficulties of acceptance by children with the norm and specialists of a child with disabilities, a negative attitude to this category of children, the complexity of the educational activities organization by teachers, the difficulties of mastering educational programs by children with disabilities -14 people (39\%).

Thus, when interpreting the responses to the questionnaire questions, we distinguish 3 levels (optimal, sufficient and low) of future teachrs readiness to work with children with disabilities. The results of the research show that 23 students (64\%) have a low level of readiness, characterized by low motivation to accept children with disabilities and fragmentary awareness of the social significance of working with children in this category; respondents admit that they are not ready to implement new teaching program, taking into account inclusive education.

A sufficient level of readiness in 12 students (33\%). It is characterized by the fact that only few future teachers adopt children with disabilities; there is sufficient awareness of the organization and conduct of socially significant work with children with disabilities. But there are no special knowledge and skills of inclusive educational process in an educational organization.

In addition, the optimal level of readiness among students is identified. It is formed only in 1 student (3\%) and is characterized by the fact that future teachers are able to accept and help children with disabilities. This is expressed in a deep awareness of the organization and conduct of socially significant work with children with disabilities in accordance with the requirements of the modern system of inclusive education. They are characterized by a sustained interest in solving the problems of children with disabilities inclusive education. There is correct, but at the same time insufficiently systematic knowledge about working with this category of children in their future professional activities.

In order to form the readiness of future teachers to work in an inclusive education at the formative stage of the experiment we implemented a special program with the use of active teaching methods, such as mini-lectures, working with text, game methods, solving situational problems, working in small groups, discussions, brainstorming, business games, project development, participation in web conferences, discussions, extensive use of internships and practices on the bases of educational organizations, where work with children with 
disabilities is presented at a high professional level, etc. Students with interest and voluntarily attended courses-additional classes at the University.

At the control stage of the experiment, a repeated diagnosis was organized to determine the level of students-future teachers readiness to work with children with disabilities, conducted using the author's questionnaire. It showed the dynamics of future teachers readiness levels to work with children with disabilities.

Thus, the results of the repeated study show that 2 respondents (5\%) have a low level; 20 respondents (56\%) have a sufficient level of readiness; 14 respondents (39\%) have an optimal level of students readiness to work with children with disabilities.

The validity of the research results was determined using a statistical method - the Pearson criterion $\chi^{2}$. To confirm the hypothesis of increasing the level of students-future teachers readiness to work with children with disabilities, it was necessary to check whether the obtained empirical data differ from the theoretical equally probable ones. In this regard, for the main hypothesis $H_{0}$ marked a uniform of the respondents group frequencies

Table 2 - distribution of empirical frequencies distribution at the ascertaining and control stage of the experiment; for the alternative hypothesis $H_{1}$ - uneven distribution. It is associated with the hypothesis of our research. An alternative hypothesis is accepted if $\chi_{\text {empirical }}^{2}>\chi_{\text {critical }}^{2}$ The value $\chi^{2}$ is calculated using the formula:

$\chi_{\text {empirical }}^{2}=\sum_{i=1}^{k \cdot l} \frac{\left(f_{\ni}-f_{T}\right)^{2}}{f_{T}}$,

According to the table of the theoretical distribution critical values $\chi^{2}$ - Pearson for significance level $\alpha=0,01$ and the number of freedom degrees $v=2$ determine the critical value $\chi_{\text {critical }}^{2}=9,2$.

Accordingly, for counting $\chi_{\text {empirical we }}^{2}$ must define the values $f_{e}, f_{\mathrm{T}}$. Summary values of the empirical frequencies $\left(f_{e}\right)$ distribution for a group of respondents at the ascertaining and control stage of the experiment are presented in table 2.

\begin{tabular}{|c|c|c|c|c|c|}
\hline \multirow{2}{*}{ Empirical frequencies } & \multicolumn{3}{|c|}{ Levels $(l)$} & Low & $\begin{array}{c}\text { Total }( \\
f_{i}\end{array}$ \\
\cline { 3 - 6 } & Optimal & Enough & 23 & 36 \\
\hline \multirow{2}{*}{ Respondents $(x)$} & $\begin{array}{c}\text { Ascertaining } \\
\text { stage }\end{array}$ & 1 & 12 & 2 & 36 \\
\cline { 2 - 6 } & Control stage & 14 & 20 & 25 & $N_{=72}$ \\
\hline \multicolumn{2}{|c|}{$\operatorname{Total}\left(f_{j}\right)$} & 15 & 32 & & \\
\hline
\end{tabular}

Table 3 shows the distribution of theoretical frequencies $\left(f_{\mathrm{T}}\right)$, which values are calculated by the formula:

$$
f_{i j}=\frac{f_{i} \cdot f_{j}}{N}
$$

Since the resulting value $\chi_{\text {empirical }}^{2}(30,9)>\chi_{\text {critical }}^{2}(9,2)$ and the level of significance in our case corresponds to $p<0,01$, then we can reject the main hypothesis and say that the introduction of a special program developed by us with the use of active teaching methods helps to increase the level of future teachers readiness to work with children with disabilities. 
Table 3 - distribution of theoretical frequencies

\begin{tabular}{|c|c|c|c|c|c|}
\hline \multirow{2}{*}{\multicolumn{2}{|c|}{ Empirical frequencies }} & \multicolumn{3}{|c|}{ Levels $(l)$} & \multirow{3}{*}{$\begin{array}{c}\text { Total }( \\
\left.f_{i}\right) \\
36\end{array}$} \\
\hline & & Enough & Low & Enough & \\
\hline \multirow[t]{2}{*}{ Respondents $(x)$} & $\begin{array}{l}\text { Ascertaining } \\
\text { stage }\end{array}$ & 7,5 & 16 & 12,5 & \\
\hline & Control stage & 7,5 & 16 & 12,5 & 36 \\
\hline & $\operatorname{Total}\left(f_{j}\right)$ & 28 & 43 & 13 & $N=72$ \\
\hline
\end{tabular}

Calculated empirical values of the criterion $\chi^{2}$ - Pearson are shown in table 4 .

Table 4-Calculation of the value $\chi^{2}$

\begin{tabular}{|c|c|c|c|c|}
\hline Respondents & Levels & Empiric. $\left(f_{\ni}\right)$ & Theoretical. $\left(f_{T}\right)$ & $\frac{\left(f_{\ni}-f_{T}\right)^{2}}{f_{T}}$ \\
\hline \multirow{3}{*}{ Ascertaining stage } & Optimal & 1 & 7,5 & 5,63 \\
\hline & Enough & 12 & 16 & 1 \\
\hline & Low & 23 & 12,5 & 8,82 \\
\hline \multirow{3}{*}{$\begin{array}{c}\text { Test } \\
\text { stage }\end{array}$} & Optimal & 14 & 7,5 & 5,63 \\
\hline & Enough & 20 & 16 & 1 \\
\hline & Low & 2 & 12,5 & 8,82 \\
\hline & & & & $\sum=30,9$ \\
\hline
\end{tabular}

\section{CONCLUSION}

Thus, as a result of the research, it was proved that specially created educational conditions for obtaining additional theoretical knowledge using active and interactive forms of education, as well as the acquisition of practical skills, undoubtedly contribute to increasing the level of future teachers readiness at the University to work with children with disabilities.

\section{REFERENCES}

1. Goryunova L.V., Romashevskaya E.S., Mareev V.I. Podgotovka pedagogicheskih kadrov dlya sistemy inklyuzivnogo obrazovaniya [Training of teachers for the system of inclusive education]. Textbook. Rostov-on-don; Taganrog: Southern Federal University Press. 2018: 120 (In Russ.).

2. Professional standard " Teacher (pedagogical activity in the field of preschool, primary General, basic General, secondary General education) (educator, teacher)", approved by the order of the Labor Ministry of Russia from October 18, 2013 N 544n.

3. Order No. 121 of March 15, 2018 "On approval of the Federal state educational institution of higher education-bachelor's degree in the direction of training 44.03.01 Pedagogical education.

4. Order No. 125 of March 15, 2018 "On approval of the Federal state educational institution of higher education-bachelor's degree in the direction of training 44.03.05 Pedagogical education (with two training profiles).

5. Romashevskaya E.S. Professional training of teachers for the system of inclusive education: search for effective conditions. Gumanitarnye nauki. 2018; 2(42): 63-68 (In Russ.).

6. Decree of the Russian Federation President, May 7, 2012 No. 597 "On measures for the implementation of state social policy".

7. Federal law "On education in the Russian Federation" from 29.12.2012 N 273-FZ.

8. Shubovich M. M., Faizova V. B. Formation of a system of value orientations that form psychological readiness for marriage among students. Vestnik Tomskogo gosudarstvennogo pedagogicheskogo universiteta. 2013; 4(132): 8994 (In Russ.).

9. Shubovich M.M. Socio-pedagogical problems of integration into society of children with disabilities and developmental disabilities. Povyshenie kachestva obrazovaniya $v$ srednej I 
vysshej shkole: mezhvuzovskij sbornik nauchnyh statej [Improving the quality of education in secondary and higher school: Intercollegiate collection of scientific articles]. Cheboksary, 2002. Pp. 166-176.

10. Shubovich V.G., Alenova A.N. Analysis of methods for assessing professional competencies. Gumanitarnye nauki I obrazovanie. 2015; 2(22): 75-78 (In Russ.).

11. Kuznetsov A., Mutaeva I., Kuznetsova Z., 2017. Diagnostics of Functional State and Reserve Capacity of young Athletes' Organism. In Proceedings of the $5^{\text {th }}$ International Congress on Sport Sciences Research and Technology support. SCITEPRESS. P. 111-115 (Scopus).

12. Erickson S.J., Robinson T.N., Haydel K.F., Killen J.D. Are overweight children unhappy? Body mass index, depressive symptoms, and overweight concerns in elementary school children. Archives of Pediatrics and Adolescent Medicine. 2000; 154(9): 931-935. DOI: 10.1001/ archpedi.154.9.931.

13. Lopes V.P., Rodrigues L.P., Maia J.A., Malina R.M. Motor coordination as predictor of physical activity in childhood. ScandinavianJournal of Medicine and Science in Sports. 2010; 21(5): 663669. DOI: 10.1111/j.1600-0838.2009.01027.x.

14. Fisher A., Reilly J.J., Kelly L.A., Montgomery C., Williamson A., Paton J.Y., et al. Fundamental movement skills and habitual physical activity in young children. Medicine and Science in Sports and Exercise. 2005; 37: 684-699.

15. Okely A.D., Booth M.L., Chey T.
Relationships between body composition and fundamental movement skills among children and adolescents. Research Quarterly for Exercise and Sport. 2004; 75: 238-247.

16. Strong W.B., Malina R.M., Blimkie C.J.R., Daniels S.R., Dishman R.K., Gutin B., Trudeau F. Evidence based physical activity for school-age youth. The Journal of Pediatrics. 2005; 146(6): 732737.

17. Wrotnial B.H., Epstein L.H., Dorn J.M., jones K.E., Kondilis V.A. The relationship between motor proficiency and physical activity in children. Pediatrics. 2006; 118: e1758-1765.

18. Ekaterina A. Fedorova, Valeri G. Shubovich, Igor O. Petrishchev. Creative activity development of students from physical culture and sports faculty on the basis of triz-pedagogy. Pedagogiko-psihologicheskie I medikobiologicheskie problemy fizicheskoj kul'tury I sporta = Pedagogico-psychological and medicobiological problems of physical culture and sport. 2016; 11(3): 143-149. DOI: 10.14526/01_1111_136 (In Russ., In Engl.)

19. Marina M. Shubovich, Larisa I. Eremina, Nadezhda V. Bibikova, Irina A. Plohova. Readiness of future teachers of physical culture to social transforming voluntary activity. Pedagogikopsihologicheskie I mediko-biologicheskie problemy fizicheskoj kul'tury I sporta = Russian Journal of Physical Education and sport. 2019; 14(2): 76-82. DOI: 10.14526/2070-4798-2019-14-2-76-82 (In Russ., In Engl.).

\section{Submitted: 29.11.2019}

\section{Author's information:}

Valeriy G. Shubovich - Doctor of Pedagogics, Associate Professor, Ulyanov State Pedagogical University, Ulyanovsk, 43270o, Russia, Ulyanovsk, Square of the 1ooth anniversary of the birth of V. I. Lenin, House 4, e-mail: shubvg@mail.ru

Olga V. Vakhteeva - Senior Lecturer, Ulyanov State Pedagogical University, Ulyanovsk, 4327oo, Russia, Ulyanovsk, Square of the 1ooth anniversary of the birth of V. I. Lenin, House 4, e-mail: olgavachteevaog@gmail.com

Alena N. Alenova - Senior Lecturer, Ulyanov State Pedagogical University, Ulyanovsk, 43270o, Russia, Ulyanovsk, Square of the 10oth anniversary of the birth of V. I. Lenin, House 4, e-mail: waterfall-_-@ $\underline{\text { mail.ru }}$ 